\title{
Barista Art: Coffee Education Strategy to The Community
}

\author{
Arifah Fathia Amani', Hanifah Ihsaniyati ${ }^{2}$ \\ ${ }^{1}$ Agricultural Extention and Communication, Faculty of Agriculture, Universitas Sebelas Maret, J1. Ir Sutami \\ No. 36 A Surakarta, Jawa Tengah 57126, Indonesia \\ ${ }^{2}$ Agricultural Extention and Communication, Faculty of Agriculture, Universitas Sebelas Maret, J1. Ir Sutami \\ No. 36 A Surakarta, Jawa Tengah 57126, Indonesia \\ hanifah_i@staff.uns.ac.id
}

\begin{abstract}
Fenomena konsumsi kopi saat ini sedang marak di kalangan anak muda sebagai gaya hidup. Kopi telah menjadi salah satu komoditas utama. Sudah biasa menemukan kedai kopi, bar kopi, dan kios. Fenomena konsumsi kopi terkait dengan peran seni seorang barista. Barista dapat dikatakan sebagai orang yang ahli dalam membuat kopi. Namun, sementara barista dikenal luas hanya untuk umum di kedai kopi meskipun banyak tempat untuk barista dapat memperkenalkan kopi, seperti di hotel, restoran, kantor atau tempat umum lainnya. Makalah ini bertujuan untuk menggambarkan peran seni barista dalam mendidik masyarakat tentang kopi. Makalah ini adalah kompilasi dari beberapa artikel jurnal dan buku yang berkaitan dengan kopi, budaya kopi, barista, dan seni membuat kopi. Referensi artikel diperoleh melalui mendeley dengan memilih referensi yang sesuai dengan setiap topik pembahasan. Topik pembahasan meliputi Budaya Kopi dan Kedai Kopi, Seni Barista, dan Edukasi Kopi melalui Seni Barista. Hasil penelitian menunjukkan bahwa keberadaan barista memiliki peran yang sangat penting dalam mendidik kopi kepada masyarakat Indonesia, khususnya mengenalkan kopi nusantara. Barista sebagai agen utama dalam penyebaran informasi tentang kopi sehingga sangat perlu memiliki karakteristik atau seni yang harus dimiliki oleh barista sebagai salah satu nilai tambah dalam penyebaran informasi tentang kopi.
\end{abstract}

\section{Kata kunci : barista, kopi, startegi, edukasi, masyarakat}

The phenomenon of coffee consumption is currently rife among young people as a lifestyle. Coffee had become one of the first global commodities. It has become common to find coffee shops, coffee bars, and kiosks. The phenomenon of coffee consumption is related to the role of a barista's art. Baristas can be said as people who are experts in making coffee. However, while barista is widely known to the public only in the coffee shop even though many places for baristas can introduce coffee, such as in hotels, restaurants, offices or other public places. This paper aims to describe the role of barista art in educating the public about coffee. This paper is a compilation of several journal articles and books related to coffee, coffee culture, baristas, and the art of making coffee. Article references are obtained through Mendeley by selecting references that correspond to each topic of discussion. Discussion topics include Coffee Culture and Coffee Shop, Barista's Action Art, and Coffee Education through Barista Art. The results showed that the existence of baristas had a very important role in educating coffee to the people of Indonesia, especially introducing archipelago coffee. Barista as the main agent in the dissemination of information about coffee so that it is very necessary to have a characteristic of art that must be possessed by the barista as one of the added values in the dissemination of information about coffee.

Keyword: barista, coffee, strategy, education, community

Proses Review : 1 - 20 Mei 2020, Dinyatakan Lolos: 26 Mei 2020 


\section{INTRODUCTION}

Coffee is one of the plantation commodities that has various types, namely Robusta, Arabica, Liberica, and Excelsa. As explained by Bhran (2010) there are two types of coffee beans that are further classified for trade in the global market: Arabica and Robusta. Coffea arabica, popularly known as Arabica coffee, grows in drier climates with mountainous elevations of 1,000 meters or more above sea level. It takes longer to reach maturity (three to five years) and is described as aromatic and flavorful by coffee connoisseurs and tasters who rank it as the highest quality specialty coffee. Its retail price may fetch from $\$ 15$ to over $\$ 25$ per pound on the global market. Arabica is distinguished from Coffea canephora or Robusta coffee, a more disease-resistant bean that grows in less time and at lower altitudes.

Coffee is a beverage that is currently being widely consumed, both among adults and young people. Solikatun et al (2015) that coffee consumption behavior is now a lifestyle and has become a popular culture so that enjoying a cup of coffee in a particular coffee shop consciously or unconsciously will differentiate individuals from others. The taste of coffee varies. Taste variations come from different coffee-producing regions, although one coffee-producing region but the taste of each different coffee plantations is indicated because of geographical factors.

The phenomenon of coffee consumption is inseparable from the existence of a coffee shop where this place is used for people to enjoy coffee. The existence of a coffee shop is also related to the barista profession. Barista is a term for people who work as coffee makers or mixers of coffee drinks, but nowadays the barista profession is not just a coffee maker, they are artists who are looking to find out the quantities and mixtures needed to make a cup of coffee and its variations. Ramadhan (2017) explains that baristas can also be considered as art mixers in the field of food or drink so that the barista profession is not just a regular coffee brewer but barista is a profession that is quite unique, promising, and can be pursued as one of the professions that can be tried by whom only. However, many people only know that a barista is a person who makes coffee in a coffee shop, even though a barista has the art and uniqueness in concocting coffee for customers.

Most people only drink coffee instead of enjoying coffee let alone the art of serving a cup of coffee. Barista art not only conveys the art of serving coffee but also efforts to provide information and education to the public about coffee. Communities in this case consumers will feel more satisfied enjoying coffee from the barista's work. The process and art of serving coffee by baristas will also increase the value of selling coffee in the coffee shop. For this reason, this paper aims to describe the role of barista art in educating the public about coffee.

\section{METHOD}

This paper comes from a compilation of journal articles and books about coffee, the culture of drinking coffee, baristas, and the art of barista coffee mixing. Reference data is retrieved via Mendeley by selecting references that correspond to each topic of discussion. Discussion topics include Coffee Culture and Coffee Shop, Barista's Action Art, and Coffee Education through Barista Art. The steps start from collecting the articles in the context of the discussion, filtering and reviewing the data, to the final stage, which is compiling into a paper.

\section{Coffee Culture and Coffee Shop}

By the seventeenth century, coffee had become one of the first global commodities. Without coffee, the world as we know it would not exist. For many societies, coffee is a customary drink and an integral part of life. Worldwide, only water, tea, milk, and perhaps soft drinks appear to be consumed more frequently than coffee (Tucker, 2017).

Drinking coffee is the final step in a chain that connects us to farmers in tropical nations around the world who produce it. Through coffee, we are intimately tied to a global economic system that has evolved over half a millennium. Coffee is the second most valuable commodity produced by developing countries (Tucker, 2017). Coffee consumption culture has existed since ancient times because consuming coffee can make some people feel happy. Kucukkomurler (2009) explain coffee is one of the most consumed beveragesSiince coffee beans imported from Ethiopia were prepared by roasting to offer it to the rulers and it was admired by many people as it has a very pleasant taste and has a distinctive place in establishing a coffee culture in the period of Ottoman.

Kjeldgaard and Jacob Ostberg (2007), coffee drinking in this part of the world has been an integral part of social life for a long time and was initially introduced in Europe during the late part seventeenth century. Some like to locate the beginning of European coffee culture in London, where British returning from travels in the Ottoman Empire brought with them the habit of drinking coffee. The first coffee house in London opened its doors to the public as early as in 1652. The London coffee culture prospered for about a hundred years but then gradually lost ground to the tea-drinking that we to this day associated with the British (Ellis 2006). Therefore, others like to point at the Turkish siege of Vienna in 1683 as the starting point. When the Turks left the city, the Turkish coffee culture was left behind and the first café was opened in 1685 in the living room of Johannes Deodat, an Armenian spy (Öberg 2005). Throughout the seventeenth century, coffee drinking was spread amongst the upper class in Europe but the habit quickly trickled down to the lower classes who drank coffee for its invigorating qualities and to cure hangovers and flatulence. 


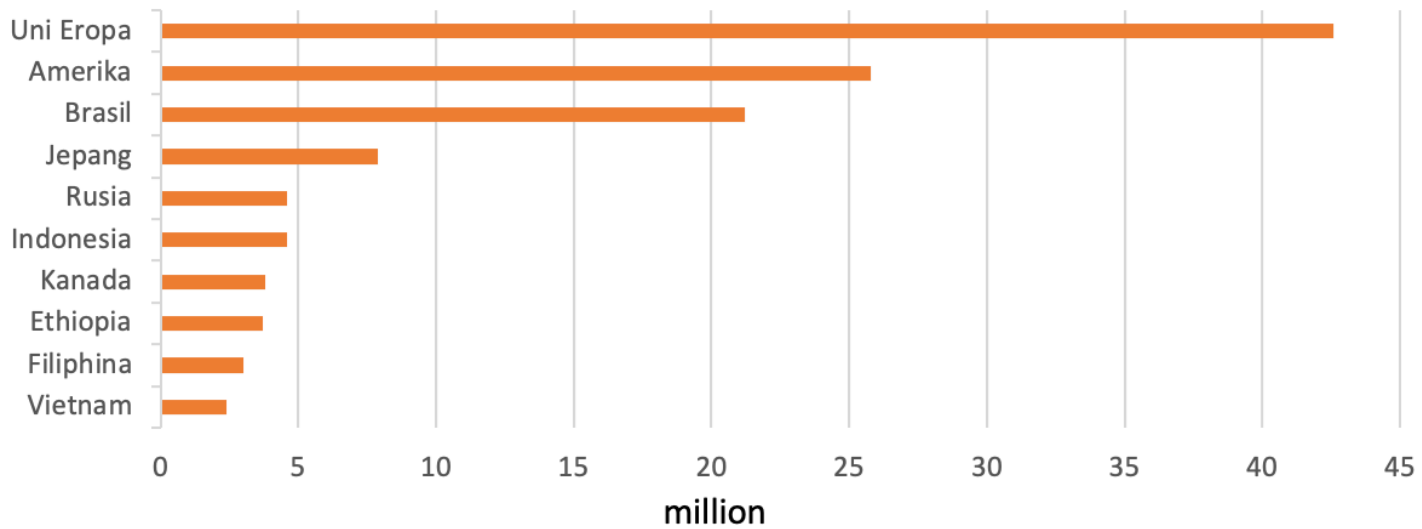

Figure 1. Data on 10 Countries with The Largest Coffee Consumption in The World (ICO, 2017)

Table 1. Projection results for coffee consumption in Indonesia in 2016-2020

\begin{tabular}{ccccc}
\hline Tahun & $\begin{array}{c}\text { Consumption } \\
(\mathrm{kg} / \mathrm{cap} / \text { year })\end{array}$ & $\begin{array}{c}\text { Total population } \\
(000 \text { people })\end{array}$ & $\begin{array}{c}\text { National Consumtion } \\
(\text { Ton })\end{array}$ & $\begin{array}{c}\text { Growth } \\
(\%)\end{array}$ \\
\hline $\left.2016^{* *}\right)$ & 1,168 & 258.705 & 302,176 & \\
\hline $\left.2017^{* *}\right)$ & 1,162 & 261.891 & 304.231 & 0,68 \\
$\left.2018^{* *}\right)$ & 1,155 & & & \\
$\left.2019^{* *}\right)$ & 1,149 & 265.015 & 306.183 & 0,64 \\
$\left.2020^{* *}\right)$ & 1,143 & 267.974 & 307.915 & 0,57 \\
\hline & 271.066 & 309.771 & 0,60 \\
\hline
\end{tabular}

Information : **) Ptojection number Pusdatin

Consumption of projection result Pusdatin

Populaion projection result BPS

For some people, drinking coffee is a must and a necessity. Coffee consumption in Indonesia is increasing every year. Evidenced by data from the International Coffee Organization (ICO) 2017, in 2000-2015 coffee consumption has increased until in 2015 it reached 4.7 million.

Traditionally Indian has the habit of drinking tea rather than coffee, which was thought as more in South Indian drinks. Over a period of time, this perception has been changing and more and more people are taking coffee. The entry of international players such as Barista, Coffee Cafe day and Starbuck has changed the scenario. It has been found the majority of respondents have satisfactory experiences with these outlets (Singh S and Saluja D, 2013).

Since their entry to Japan in the latter half of the 19th century, coffee and coffee shops have been closely linked to the economic, political, and socio-cultural change undergone by Japanese society. The cafés themselves have gone through numerous transformations in order to address the various social needs of their patrons. Today, coffee shops occupy a significant niche in the Japanese urban lifestyle (Grinshpun, 2014).

For some people, drinking coffee is a must and a necessity. Coffee consumption in Indonesia is increasing every year. Evidenced by data from the International Coffee OrganizationAccording to the AEKI or the Indonesian Coffee Exporters Association the rate of consumption per capita of society in 2017 rose to $1.2 \mathrm{~kg}$ of coffee and in 2018 predicted to be at $1.4-1.5 \mathrm{~kg}$ of coffee. There are also projection data that explain the consumption of coffee for the people in 2016-2020. (ICO) 2017, in 2000-2015 coffee consumption increased until in 2015 it reached 4.7 million.

The culture of drinking coffee is currently practiced by several groups in coffee shops. Most people come to the coffee shop not only to drink coffee but also to relax. Sen (2009) said ninety-seven percent of the visitors are between the age group of twenty to thirty years and are either students or young professionals belonging to the upper, upper-middle and middle classes, out of whom, forty-five 
percent are regulars to these shops. They all reported having taken up this habit of coming to the coffee shops to drink coffee during the end of their school days and early college life. They felt that the place is a good ,hangout ${ }^{\text {ee }}$ for their friends with a perfect ambiance that suits "catch-

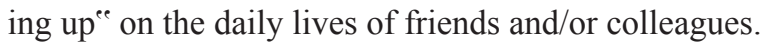

Coffee shops have become a global phenomenon. It has become common to find coffee shops, coffee bars, and kiosks in places where they were once rare or nonexistentHong Kong, Mexico City, Dublin, Rio de Janeiro, Tokyo, Sydney, New Delhi, or Johannesburg, and almost every major airport on the planet. Many factors contributed to the expansion, including the globalization of consumer culture, growing appreciation of high-quality coffee, and the public's eager acceptance of casual spots to study, relax, socialize, or pick up an energizing drink. Coffee shops have become so ubiquitous that it is fair to say that they have impacted global culture Tucker, 2017).

\section{Barista's Action Art}

The coffees served in a coffee shop as a type of retail establishment are more than a commodity for people who consume the experiences afforded by these coffee shops (de Vasconcelos Teixeira L, 2020). Consumers in the coffee shop not only drink coffee but also enjoy the way coffee is served by the barista.

In the hands of a barista, coffee is also an art (Izak, 2013). Each barista has a unique way of making coffee. They also have a formula for making delicious coffee according to them. As explained by Egger dan Rubby (2014) each barista has its own formula, and prevailing tastes have changed over time. It could have been invented in Australia or New Zealand, or it could have less and slightly hotter milk than a latte, but it will be served in a cup and it will contain $30 \mathrm{ml}(1 \mathrm{oz})$ of espresso. Outside that, there's no right or wrong. Make it how you like it.

Through the art that is owned by the barista, it will also increase the selling price of coffee. Doorn et al (2015) in their research produced that visual presentation of food can exert a profound effect on how much people are willing to pay and, on occasion, can even affect the consumer's enjoyment of the food. Likewise, the coffee is more unique or the more baristas have the art of making coffee, the selling price of their coffee products is increasing like one of the arts that baristas have in brewing coffee with latte art. Average latte art has a higher price compared to espresso, americano, v60, mochaccino and others.

\section{Coffee Education through Barista Art}

Currently, there are terms of specialty coffee. Coffee specialty according to Kopitem.com is a classification of coffee that has a special aroma and taste. In Indonesia, specialty coffee is already familiar. Based on data accessed from the website www.specialtycoffee.co.id Indonesia has many types of specialty coffee. Call for example Lintong Coffee, Mandheling Coffee, Gayo Mountain Coffee, Toraja Coffee, Kalosi Coffee, Kintamani Bali Coffee, Flores-bajawa Coffee, Baliem Highland Coffee (Papua Wamena), Java Estate Coffee, Java Preanger Coffee, Java 'Kopi Luwak' Arabica, and Luwak Coffee.

Knowledge about the product is very important so that it can influence consumers to buy products and the ultimate goal is to consume them later. It's the same with the importance of education about coffee. If someone already knows coffee then that person will be interested, buy and consume. How to educate this coffee one of which can be given through barista activities.

Barista is a coffee compounding term. Barista is a very important person in a coffee shop. Baristas with speed, friendliness, skills in mixing coffee, serving and serving consumers ranging from coming to the coffee shop until later consumers finish enjoying coffee. Blake et al (2005) explain baristas make coffee for the masses, listen sympathetically to the woes of their customers, and maintain conducive environments for information flow.

In observations made by Blake et al (2005) noted how well baristas and customers know each other played a part in information sharing. Those who knew each other well shared extensive information about families and activities. When the relationship was less established, the depth of information exchange reflected this. Information flowed in every direction, regardless of the topic. The triad of exchange moved from barista to barista, barista to a customer, and customer to customer. This social network is inherent to the function of a coffee shop, but how it is achieved is what information scholars will be interested to study. This shows that the importance of communication between baristas is very much needed and can be used by baristas to convey information about coffee.

Baristas have the art of serving coffee. A barista must be able to communicate well with customers through the way he makes coffee. Some baristas in hotels, restaurants or restaurants usually brew coffee or other food in the kitchen so they cannot communicate directly with customers. However, if the barista's coffee shop is not behind the kitchen, the barista is behind the bartender where the place where he mixes coffee is displayed along with complete tools that support his work. Also, coffee shops always line their coffee products on tables where there are various kinds of coffee makers. The goal is that customers can find out various types of coffee and choose which coffee will be enjoyed and blended by a barista.

Not separated from the role of baristas to introduce coffee to customers. Being a barista we have to start a lot of conversations with customers. It should not be silent, because one way to introduce coffee to customers is through com- 
munication between the customer and the barista. Laurier (2012) explains they (barista) should keep talking to the customer while making their order and try their best never to turn their backs on them. For the beginner barista who is still spelling out recipes, trying to recall orders and trying not to press the wrong buttons on the machine, turning their back on the customer is pretty much inescapable and excusable for the time being.

To find out the different types of coffee, people do not need to be a barista but through a barista in coffee and wherever you can get to know coffee as said by Egger and Rubby (2014) in his book Home Barista, you don't have to be a roaster to be a great barista, but knowing a bit about how your coffee is roasted can give you a new understanding of the power of the bean. You've probably been to a café where a huge coffee roaster is on display, churning away to its precise instructions (if you haven't, you should-it's pretty impressive). Like much of the coffee industry, this process was hidden for a long time but is now opening up to professionals and amateurs alike.

\section{CONCLUSION}

Barista art is a matter that is viewed by the public as the culture of coffee as lifestyle increases because barista art is one way to educate coffee to the public. Drinking coffee is more delicious when at the same time seeing how baristas brew coffee that will be served to customers. Each barista has a different art in mixing coffee because each water temperature, pouring, measuring coffee, and time in brewing can make the coffee have a different taste. The art that is owned by baristas can also affect the selling price of coffee drinks in a coffee shop. Through the art of barista, ordinary people who previously did not know about coffee will become less aware of coffee because in every process of compounding the barista must be able to inform customers about the coffee that is being made so that when people already know about coffee, people are expected to start buying and consuming it.

\section{REFERENCES}

AEKI .(2017). Data the number of people per capita consumption in 2017. Retrived from http://www.aeki-aice. org/data_dan_konsumsi_aeki.html

Bhran, H. S. (2010). Coffee, Culture and Intellectual Property: Lessons for Africa from the Ethipian Fine Coffee Inotiative. Boston University Creative Services. Retrived from https://www.bu.edu/pardee/files/2010/09/Pardee-Paper-11-Ethiopian-Fine-Coffees.pdf

Blake, K., Aimee B., Jane P., Collen K. (2005, November 15). The Information Behaviour of The Barista. Retrived from http://faculty.washington.edu/harryb/courses/ LIS510/Assign_2/Team_7_Barista.pdf
De Vasconcelos Teixeira, L. (2020). The consumption of experiences in specialty coffee shops. Coffee Consumption and Industry Strategies in Brazil, 275-295. doi:10.1016/ b978-0-12-814721-4.00010-x

van Doorn, G., Colonna-Dashwood, M., Hudd-Baillie, R., \& Spence, C. (2015). Latté Art Influences both the Expected and Rated Value of Milk-Based Coffee Drinks. Journal of Sensory Studies, 30(4), 305-315. https://doi. org/10.1111/joss. 12159

Egger, S. And Ruby A. (2014). Home Barista: How To Bring Out The Best In Every Coffee Bean. Ebook ISBN 978-1-61519-293-9. Australia: Affirm Press.

Grinshpun, H. (2013). Deconstructing a global commodity: Coffee, culture, and consumption in Japan. Journal of Consumer Culture, 14(3), 343364. doi:10.1177/1469540513488405

International Coffee Organization (ICO). 2017. Data on 10 Countries with The Largest Coffee Consumption in The World

Izak. (2013). Great art starts with a bean : consumer savvy Kjeldgaard, D., \& Ostberg, J. (2007). Coffee Grounds and the Global Cup: Glocal Consumer Culture in Scandinavia. Consumption Markets \& Culture, 10(2), 175 187. doi:10.1080/10253860701256281

Kopi specialty. Kopitem.com Retrieved from https://kopitem.com/tentang-kopi/pengertian-kopi-specialty/

Kucukkomurler, S., \& Özgen, L. (2009). Coffee and Turkish coffee culture. Pakistan Journal of Nutrition, 8(10), 1693-1700. https://doi.org/10.3923/pjn.2009.1693.1700

Laurier, E. (2013). Becoming a Barista. In Café Society (pp. 127-145). Palgrave Macmillan. https://doi. org/10.1057/9781137275936

Raharjo, B. T. (2013). Analisis Penentu Ekspor Kopi Indonesia. Jurnal Ilmiah. Universitas Brawijaya Malang.

Ramadhan, A.D. (2017). The expert hands from yogyakarta (barista). e-Proceeding of Management Telkom University ISSN : 2355-9357, 4(2), 2027-2053.

Sen, P. (2009) Coffee House to Barista: A study of cultural change. Dissertation submitted under the guidance of $d r$. dalia chakraborty reader, department of sociology jadavpur university https://www.academia.edu/28047403/ COFFEE_HOUSE_TO_BARISTA_-_A_Study_of_Cultural_Change 
Singh, S., \& Saluja, D. (2013). Customer Satisfaction Study of Barista Coffee. European Journal of Commerce and Management Research(EJCMR), 2(6), 118-122.

Solikatun, Drajat T K, Argyo D. (2015). Behavior of Coffee Consumption as a Culture of Consumption Society: Phenomenology Study of Coffee Drinkers in Semarang City Coffee Shop.(Perilaku Konsumsi Kopi Sebagai Budaya Masyarakat Konsumsi: Studi Fenomenoloi Pada Peminum Kopi di Kedai Kopi Kota Semarang). Jurnal Analisa Sosiologi, 4(1), 60-74.

Tucker, C. M. (2017). Coffee culture: Local experiences, global connections: Second edition. Coffee Culture: Local Experiences, Global Connections (pp. 1-164).

TaylorandFrancis.https://doi.org/10.4324/9781315678795 